\title{
FACTORS INFLUENCING INSURANCE FOR YOUNG PEOPLE
}

\author{
UDC: $368.91-053.81$ \\ Original Scientific Paper \\ Bruno ZAVRŠNIK ${ }^{1}$ \\ ${ }^{1}$ University of Maribor, Faculty of Economics and Business, SI-2000 Maribor, Razlagova 14, Slovenia \\ E-mail: bruno.zavrsnik@um.si
}

Paper received: 07.05.2021; Paper accepted: 27.05.2021

\begin{abstract}
Present times are changing rapidly, people are becoming increasingly active, and we often find ourselves in a situation over which we have no control. Nowadays we know many types of insurance with which we can take care of our financial security. It is important for individuals to choose the most appropriate type of insurance according to their needs and life span. It is extremely important for young people to start saving for their future as soon as possible in the type of life insurance. The main objective of this paper is what proportion of young people already have insurance or are already thinking about it and why not. We were also interested in what the decisive factors are that make young people decide to buy insurance and why not. Research has shown that young people are aware of the importance of insurance, but most of them do not have adequate financial resources and are insufficiently informed about the types of insurance.
\end{abstract}

Keywords: Insurance; Life insurance; Influencing factors; Young people.

\section{INTRODUCTION}

Insurance is any kind of program that allows people to protect themselves from major disasters by combining their risks with other people's and paying into a pool, which will pay out money if you experience a specific kind of adversity like illness, injury, death, or car damage (Bieber, 2019).

Insurance is not something that you will read, talk or buy it every day, like watching a series on Netflix or Amazon. But surely, something to think about as dearly as you think of yourself and of your family. Especially, if it can cost you and your family more than you can ever imagine.

Insurance, in a simple language, can be stated as a financial safety net against the loss that may cause a hole in your pocket. Not only that, without insurance, you may end up breaking up your life savings. No matter how healthy you think you are or even if you hit the gym every day and follow a diet, an unforeseen event such as suffering from a chronic disease, terminal life illness or disability caused due to an accident or even death, may flip things upside down. It is a known fact now, irrespective of age, gender, and lifestyle, anyone can be a victim of such eventualities.

And that is where insurance comes as a protective shield, offering a source of financial aid in the need of hour. Like a true friend.

There are different types of insurance. It is important to know the types of insurance, its purpose, and which one you should opt for. The interesting fact is that these days almost all types of insurance products are available online. Moreover, insurance products can be studied, analyzed and purchased online. Compare various insurance products online and opt for the most suitable one.

Insurance is divided into two types: General and Life Insurance.

a) General Insurance - It implies protection that does not include a human life of the insured. A General Insurance plan can be opted to get a cover, a protective shield for car, bike, health, travel, home, etc. The insurance company promises to pay the compensation for the loss incurred to the insured based on indemnity, as a 
promise against the premium that the policy holder pays.

b) Life Insurance - It covers the insured or his family against financial losses that may occur due to untimely death or permanent disability of the insured. Apart from coverage of the life assured, life insurance comes with different options. There are various life insurance products that come with an opportunity of investment and savings along with the life cover (Sumit, 2017).

Life insurance is not an easy thing to talk about. There are probably innumerable things that people would rather do than discuss insurance, such as laundry or dental work (Leong, 2013).

Young adults from 19 to 29 years of age have historically been uninsured at higher rates than any other age group, not because of a lack of desire for health coverage but because they have lacked access to affordable health coverage - only 64 percent of young adults had health insurance coverage in 2010.

One major reason why young adults have been uninsured at such high rates is a disproportionate number of young adults lack insurance because of the type of work they do. Many people in their early 20s perform low-income or temporary jobs employment that rarely offers health insurance (Calsyn \& Rosenthal, 2013).

Risk aversion is an important reason why people decide to buy insurance in general even though they must pay for insurance premium more than mathematical expectation of loss. Thus, it is expected that risk aversion has positive effect on life insurance purchase as well. It is common in empirical researches to use education as proxy of risk aversion (Tacadena, 2019).

Thus, education increases risk aversion and encourages people to demand life insurance. Additionally, individuals with higher education have higher income and can expect that the income will continue to increase at faster rate and in long term compared to those with lower level of education. Consequently, more life insurance will be purchased by more educated individuals (Ćurak et al., 2013).

The main goal of this paper is to investigate and examine the decisive factors for young people up to the age of 35 to decide to buy insurance or not.
We achieved this goal based on research. Data for this research is collected through an online survey. For this purpose, we reviewed and analyzed existing literature and resources on the Web.

After presenting the theoretical background, we also described the research methodology. The results were presented in tables and figures. A discussion follows where we analyse these results.

\section{THEORETICAL BACKGROUND}

Over the past several years - since the economic crisis came to an end - industry experts have been concerned with the number of young adults who are going without life insurance. While most age groups saw diminished enrolment after the initial onset of the recession, many age groups have returned to their pre-recession levels. But interest among millennials remains somewhat muted.

Several factors could be blamed for this, including the fact that millennials do not feel as though they have anyone to protect financially if they are unmarried or without children, as well as the (erroneous) idea that life insurance is something they really cannot afford. Indeed, many polls show that while most Americans of any age dramatically overestimate the cost of such coverage, the problem is particularly pronounced and more widespread among the youngest group of adults (Gillespie, 2015).

To that end, financial experts say the best thing that young people can do when it comes to being prepared for life insurance is work to gain a better understanding of how it works, why it is needed, and when to buy, according to a report from the consumer financial advice site Doughroller. One of the biggest reasons young people may not get it the notion that if they do not have a family to support, it is just not a worthwhile investment - is actually incorrect. The younger generation should consider funeral expenses and repayment of outstanding debt in order to ease the burden on spouses or dependents (Morrow, 2021).

Key informants universally reported that young adults struggle to understand and navigate our health system, especially when churning between health insurance plans. Key themes were that many young adults lacked knowledge about insurance concepts, understanding of the rights and responsibilities of users, and familiarity with using the health care system. Health insurance resources 
focus on enrolment over navigation, are in unfavourable formats for many young adults, and are separated by health plan or program. Resources should be provided through institutions connected to young adults and reach those with high health insurance literacy needs, (Tilley et al., 2018).

The research increasingly highlights the importance of health insurance literacy for building strong care connections and maintaining health, (Levitt, 2015). These skills are necessary for reading health care notices, understanding insurance cost-sharing designs, and communicating with health care providers (Peerson \& Saunders, 2009). One study showed young adults demonstrating poor health insurance literacy when asked to define common health insurance terms, with $48 \%$ incorrectly defining deductible and $78 \%$ incorrectly defining coinsurance (Wong et al., 2015).

Health insurance literacy levels may contribute to the lack of health insurance coverage among young adults because of their inability to purchase and understand health insurance plans. The high cost of health insurance may also discourage young adults from purchasing health insurance. In a recent health insurance survey, 50 percent of participants responded that their primary reason for not purchasing health insurance is because they cannot afford it (Cantiello et al., 2015).

Young adults from 19 to 24 years of age are often termed as the "young invincible" by the media. Many young invincible consider themselves healthy and immune to many health problems and because of this there is a common belief that it may be the reason why many young adults deicide not to purchase health insurance.

Although young invincible perceive themselves to be in good health and choose not to purchase health insurance, many of them may be jeopardizing their health for the future. Many young adults already have single or multiple chronic illnesses, and more importantly, many are engaging in lifestyle behaviours that may affect their risk of disease in the future (Yang, 2016).

At least part of the reason why you should get life insurance when you are very young is that you can get it before any chronic health conditions develop. For most people, the ideal time to buy life insurance is when you are in your twenties. It will be less expensive to purchase life insurance now, while you are young and in excellent health, than it may be a few years down the road when you have a family to care for (Dorsey, 2018; Mercadante, 2021).

Life insurance demand has experienced a rapid growth over the last few decades, both as provider of financial services to consumers and as a major investor in the capital market. But, the growth of life insurance did not rise at the same level, not only among industrial countries and developing countries, but also there is a difference between developing countries. The large disparity across countries in the use of life insurance raises questions about what causes this variation and thus what determines life insurance consumption. A number of authors have proposed a variety of different socio-economic and institutional factors as possible determinants of life insurance consumption (Kjosevski, 2012).

The young adult population is cost sensitive. A major reason why so many young adults do not purchase health insurance is the rising cost of health insurance (Cantiello et al., 2015). Similarly, in a study investigating college students' perceptions of health insurance, almost 50 percent of 1,367 students perceived the cost of health insurance as too expensive (Price et al., 2010). When considering the cost of health insurance coverage, it is important to weigh the benefits of cost versus protection. Similarly, of sampled young adults in the Deloitte research, 2,014 who decided not to purchase health insurance, few responded that it was because of their chances of getting sick, however many reported that it was the perception of cost versus the expected benefits (Deloitte Center for Health Solutions, 2015).

Age- and life-stage-specific factors likely play a role in these low coverage rates. For example, young adults may be disproportionately concentrated in entry-level jobs without benefits, and, until recently, restrictions related to age and college enrolment rendered many young adults' ineligible for coverage on their parent's insurance plans. Recent polls suggest that three-quarters of young adults' view health insurance as important, but many see cost as a barrier to obtaining coverage (Staley \& Carlson, 2014).

\section{METHODOLOGY}

We prepared an anonymous survey questionnaire among young people in the age group between 18 and 35 years. We used the $1 \mathrm{Ka}$ website to conduct 
the research. The survey questionnaire consisted of closed-ended questions and answers on a five-point Likert scale. The labels of each of the Likert scale were: 1 - Totally Disagree; 2 - Disagree; 3 Neither; (4 - Agree; 5 - Totally Agree.

It was sent among individuals in electronic form through social networks. 101 individuals from all over Slovenia started participating in the survey, 10 questionnaires were incomplete, 91 questionnaires of the survey completed in full, and one individual did not belong to the appropriate age group.

In the following we used data from the survey in the research, which were solved completely and adequately. The total number of respondents for carrying out a market survey was 90 of this, 56 were women and 34 were men.

\section{RESEARCH RESULTS}

The purpose of this research is to investigate and examine the decision-making factors that young people decided for insurance and why not.

First, we wanted to know the age of the respondents.

Table 1: Age of the respondents

\begin{tabular}{|c|c|c|}
\hline Age & Frequency & Percent \\
\hline From 18 to 25 & 27 & $30 \%$ \\
\hline From 26 to 30 & 45 & $50 \%$ \\
\hline From 31 to 35 & 18 & $20 \%$ \\
\hline Total & 90 & $100 \%$ \\
\hline
\end{tabular}

Most respondents (45) belong to the age group from 26-30 years.

Table 2: Level of education

\begin{tabular}{|c|c|c|}
\hline Education & Frequency & Percent \\
\hline College or higher & 54 & $60 \%$ \\
\hline High School & 24 & $27 \%$ \\
\hline $\begin{array}{c}\text { Vocational or } \\
\text { technical school }\end{array}$ & 10 & $11 \%$ \\
\hline Primary school & 2 & $2 \%$ \\
\hline Total & 90 & $100 \%$ \\
\hline
\end{tabular}

Table 2 shows that most respondents have a college or higher degrees.

When asked respondents if they had their own income, $77(86 \%)$ answered that they had and 13
(14\%) answered that they did not have income yet. The result is shown on Figure 1.

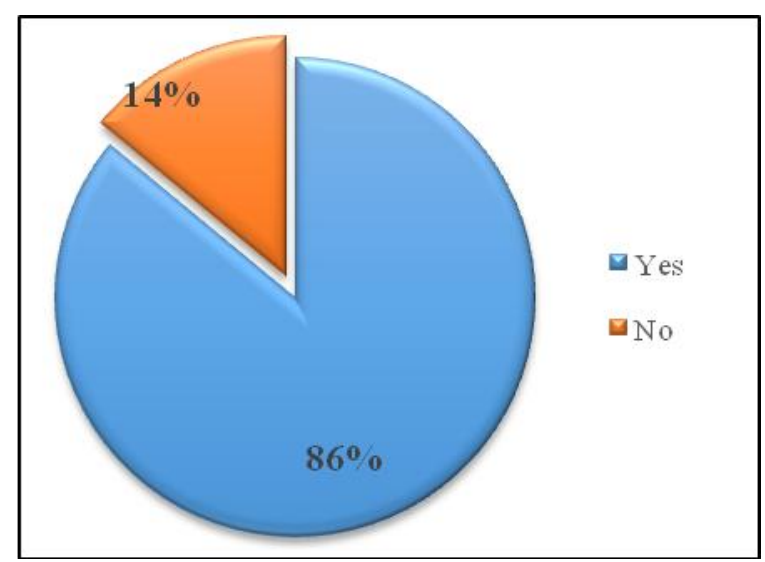

Figure 1: Respondent's income

Table 3 shows the respondents' answers regarding their opinion on insurance. 49 (54\%) answered that they had a positive opinion, and 41 (46\%) answered that they had a negative opinion about insurance.

Table 3: Opinion on insurance

\begin{tabular}{|l|l|l|}
\hline $\begin{array}{l}\text { Opinion of } \\
\text { Respondents }\end{array}$ & Frequency & Percent \\
\hline Positive & 49 & $54 \%$ \\
\hline Negative & 41 & $46 \%$ \\
\hline Total & 90 & $100 \%$ \\
\hline
\end{tabular}

When asked based on which they formed their opinion regarding insurance, 49 respondents $(54 \%)$ answered that they had their own experience, 47 $(52 \%)$ respondents said that they formed their opinion based on the opinion of their family members and friends, $7(8 \%)$ of respondents answered that they formed their opinion based on the media, and $11(12 \%)$ respondents answered that they formed their opinion based on something else. The results are shown in Figure 2. Several answers were possible.

The question of which type of insurance the respondents chose was answered only by those who had already had a meeting with an insurance agent. $20(51 \%)$ answered that they chose accident insurance, $14(36 \%)$ answered that they decided to insure and save at the same time, $13(33 \%)$ did not buy an insurance, $9(23 \%)$ buy insurance against serious illness and $7(18 \%)$ buy death risk insurance. This is presented on Figure 3. 


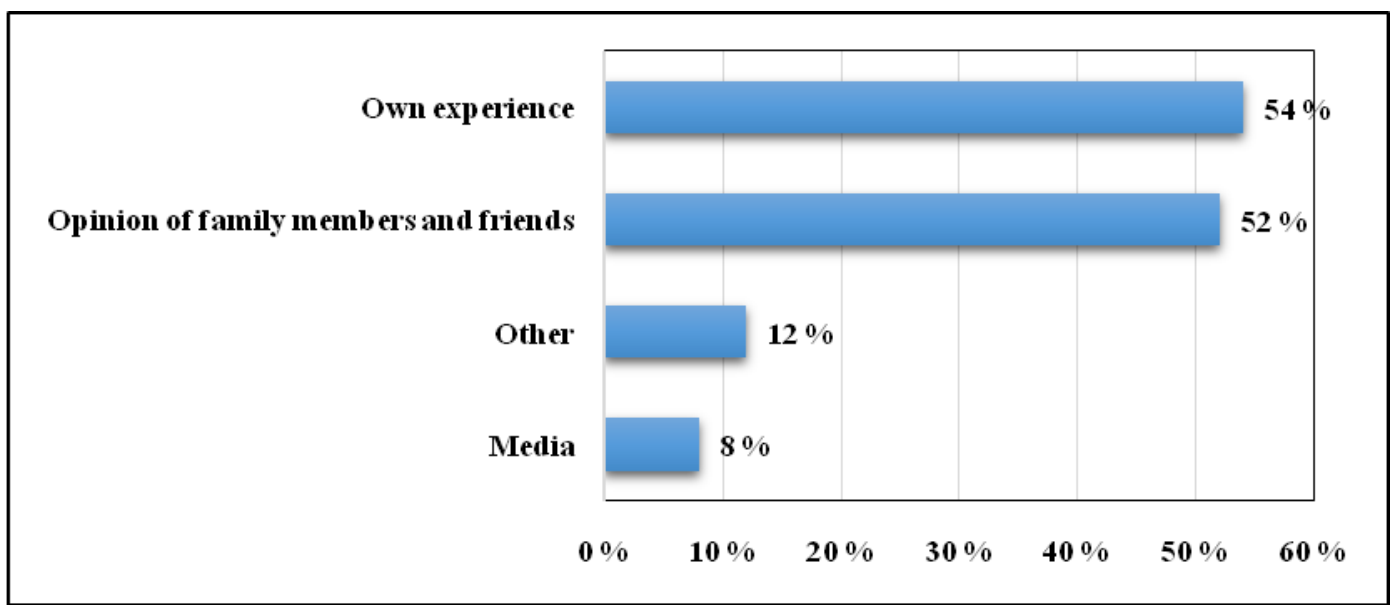

Figure 2: Forming an opinion

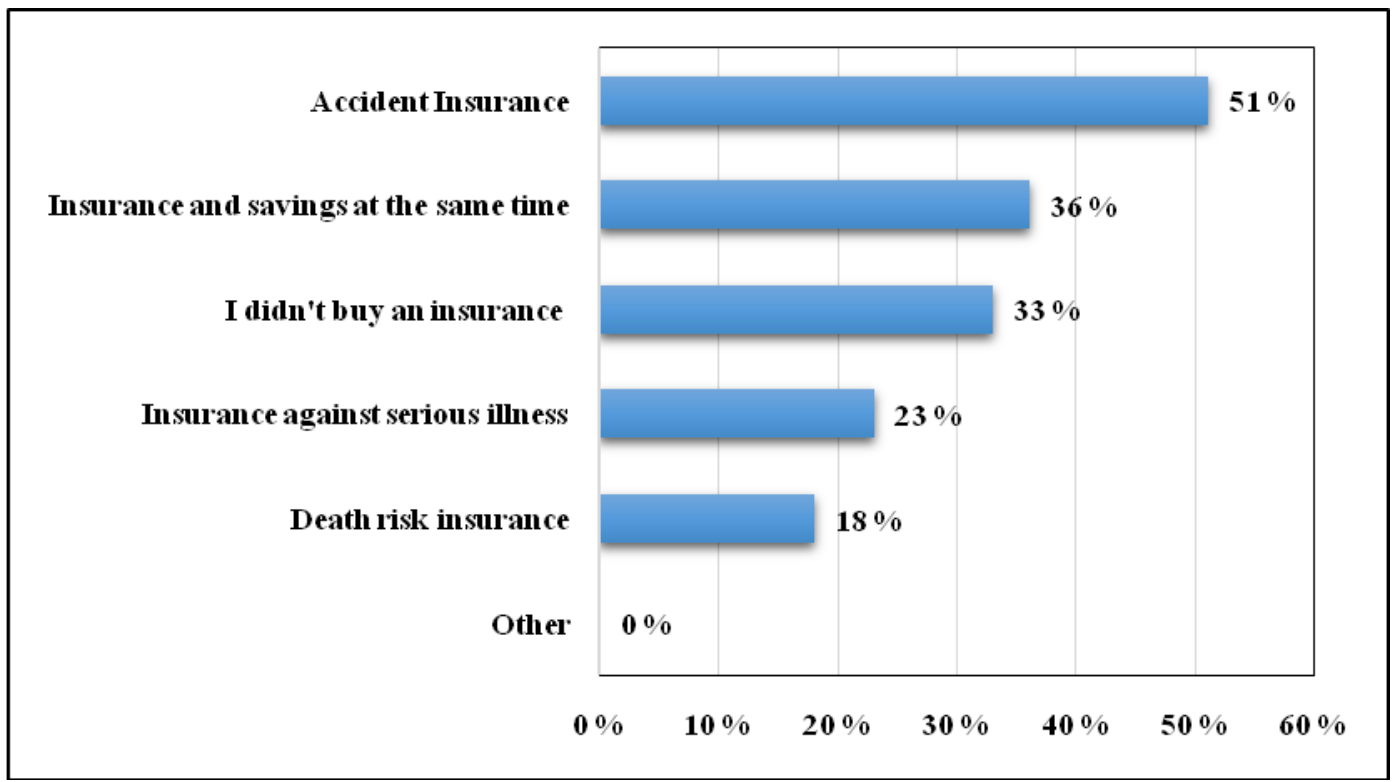

Figure 3: Type of insurance

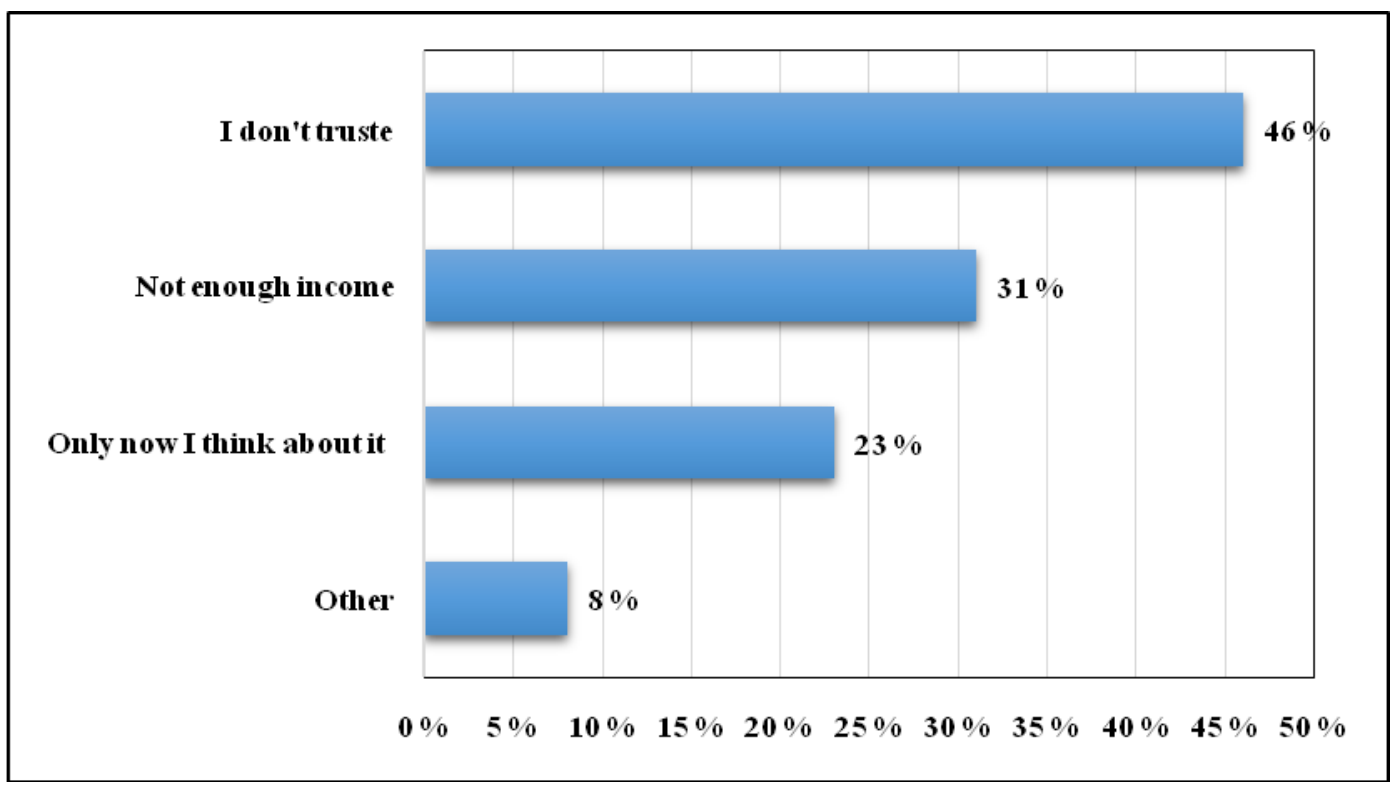

Figure 4: Reasons not to buy insurance 


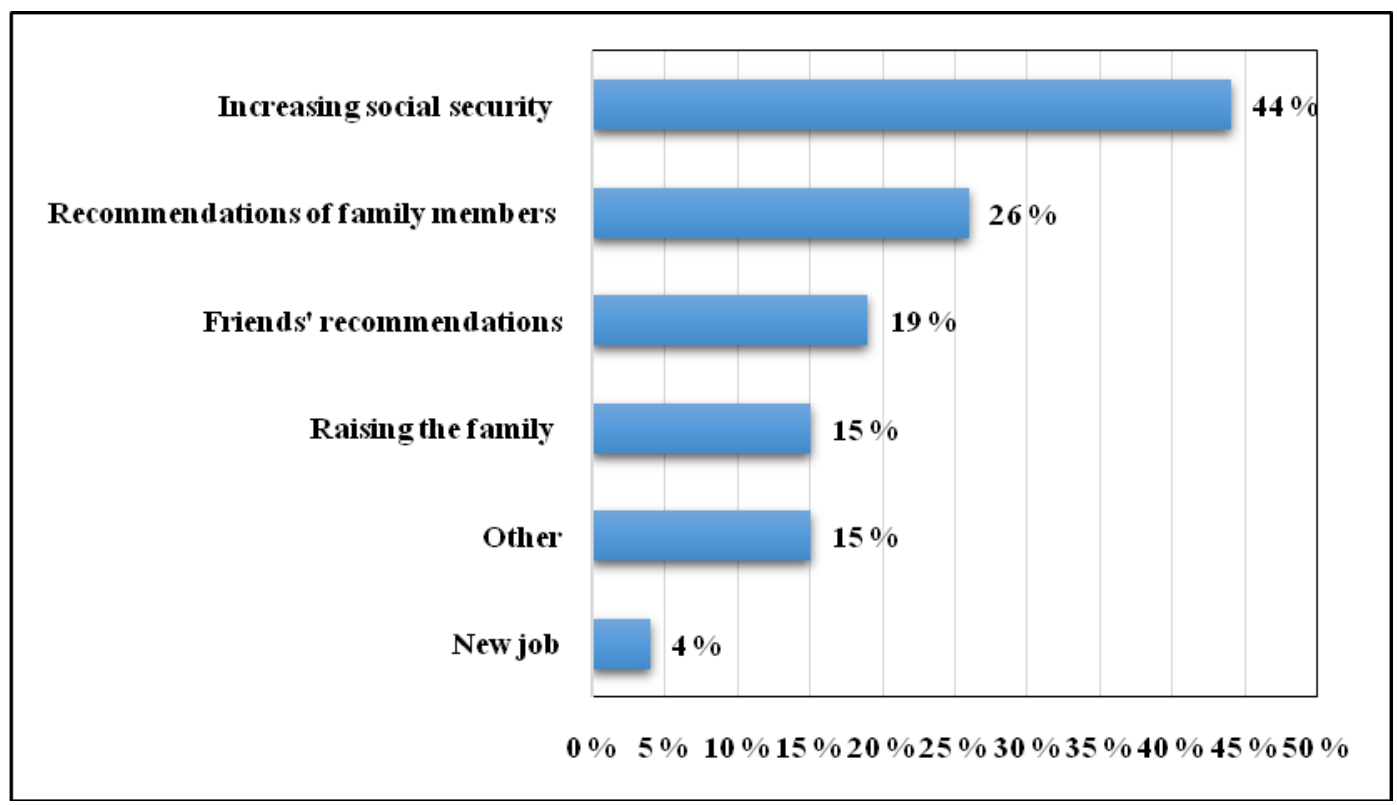

Figure 5: Reasons to buy insurance

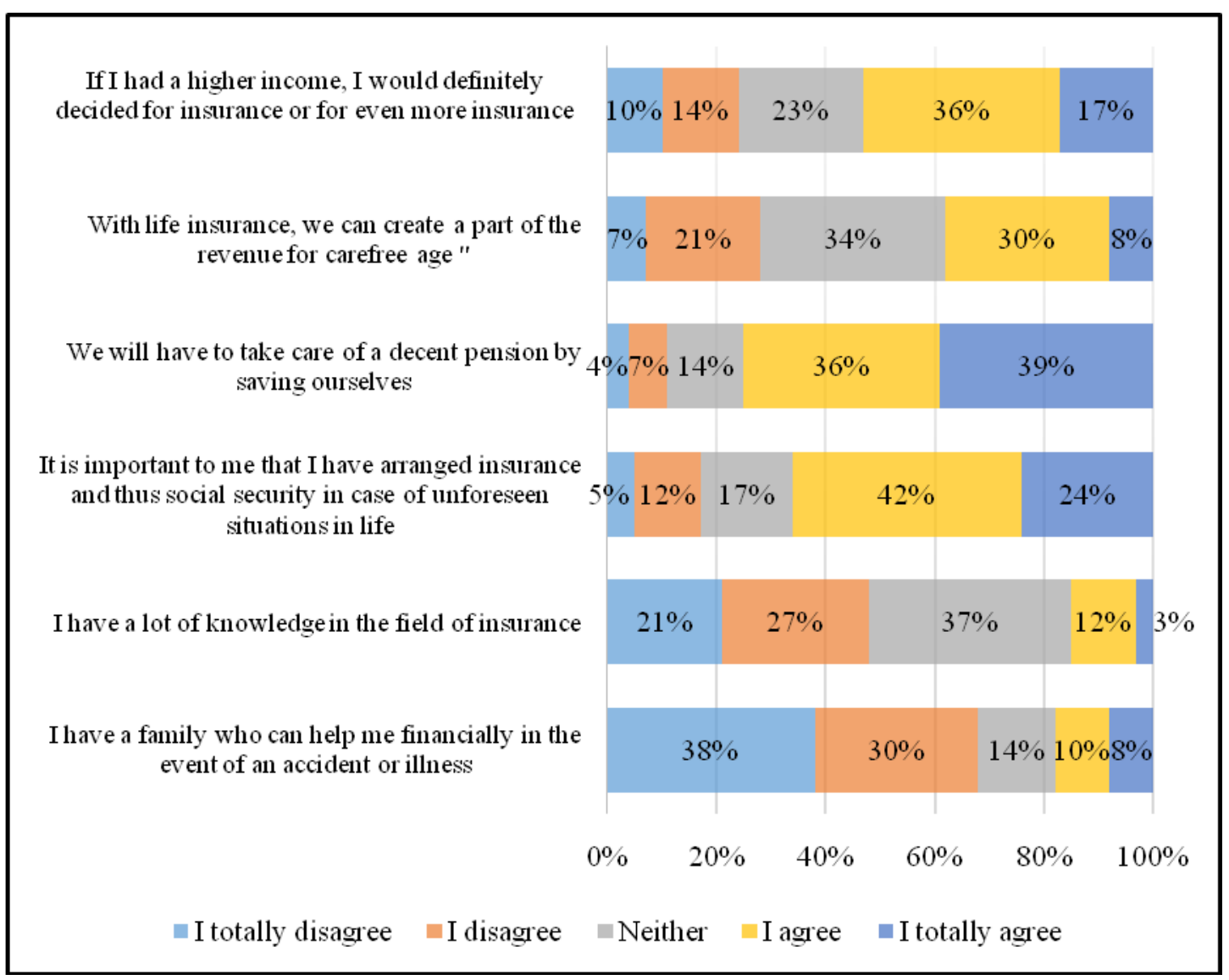

Figure 6: Evaluation of respondents' statement

The respondents who answered the previous question that they did not buy insurance, gave the main reasons for this. When asked respondents what the main reason was not to buy insurance, 6 (46\%) answered that they did not trust insurance companies, $4(31 \%)$ did not buy insurance because they had insufficient income and $3(23 \%)$ were only now thinking about buying insurance. The answers are in Figure 4. 
When asked what the main reason was for buying insurance, most respondents 12 (44\%) answered that the reason was in increasing social security, 7 $(26 \%)$ bought insurance due to the recommendation of close family members, 5 (19\%) received recommendation from friends, 4 (15\%) responded that there were other reasons to buy insurance, 4 (15\%) bought insurance because they enlarged the family and one (4\%) said the reason was a new job. Respondents' answers can be seen in Figure 5.

When asked if they were currently thinking about insurance, 75 (84\%) respondents said no, and 15 (17\%) respondents were thinking to buy insurance now. The results are shown in Table 4.

Table 4: Thinking about the insurance

\begin{tabular}{|c|c|c|}
\hline $\begin{array}{c}\text { Respondents' } \\
\text { Answers }\end{array}$ & Frequency & Percent \\
\hline No & 75 & $84 \%$ \\
\hline Yes & 15 & $17 \%$ \\
\hline Total & 90 & $100 \%$ \\
\hline
\end{tabular}

At the end of the research, we made some statements to the respondents, to which they answered with agreement or disagreement. The answers are shown in Figure 6.

\section{DISCUSSION}

The results of this study indicate that most young people up to 35 have a negative opinion about insurance. This means that insurance companies should devote much more communication to young people.

When asked respondents on what basis they formed their opinion regarding insurance, 54\% answered that they had their own experience, $52 \%$ of the respondents said that they formed their opinion based on the opinion of their family members and friends and $8 \%$ respondents answered that they formed their opinion based on the media.

The question of which insurance they chose was answered only by those who had already had a meeting with an insurance agent. 51\%answered that they bought accident insurance, $36 \%$ bought for insurance and savings at the same time, $33 \%$ did not buy any insurance, $23 \%$ respondents bought serious illness insurance and $8 \%$ bought death insurance.
Figure 6 shows the opinion of the respondents regarding various statements that are important in the field of various insurance issues.

The statement "I have a lot of knowledge in the field of insurance", $21 \%$ respondents answered that they totally disagreed, $27 \%$ answered that they disagreed, $37 \%$ were undecided, $12 \%$ answered that they agreed and 3\% that they totally agreed with the statement.

The statement "It is important to me that I have arranged insurance and thus social security in case of unforeseen situations in life. (Death, accident, serious illness)", 4 5\% respondents answered that they completely disagreed, $12 \%$ answered that disagreed, $17 \%$ were undecided, $42 \%$ answered that they agreed and $24 \%$ that they totally agreed with the statement.

The statement "I have relatives who can help me financially in the event of a serious accident or illness (amount over $€ 100,000$ )", 38\% respondents answered that they totally disagreed, 30\% answered that disagreed, $14 \%$ were undecided, $10 \%$ answered that they agreed and $8 \%$ that they totally agreed with the statement.

The statement "We will have to take care of a decent pension by saving ourselves", 4\% respondents answered that they totally disagreed, $7 \%$ answered that they disagreed, $14 \%$ were undecided, $36 \%$ answered that they agreed, and $39 \%$ that they totally agreed with the statement.

The statement "With life insurance we can generate part of the income for a carefree age", 7\% respondents answered that they totally disagreed, $21 \%$ answered that they disagreed, $34 \%$ were undecided, $30 \%$ answered that they agreed, and $8 \%$ that they totally agreed with the statement.

The statement "If I had a higher income, I would definitely opt for insurance or for even more insurance", $10 \%$ respondents answered that they totally disagreed, $14 \%$ answered that they disagreed, $23 \%$ were undecided, $36 \%$ replied that they agreed and $17 \%$ that they totally agreed with the statement.

These findings have significant implications for the understanding of how young people think about all types of insurance and what insurance companies should do to bring their services closer to them in a friendly and accessible way. 
The results of this research also show that society has not done enough for young people to inform and ensure their social and economic security.

\section{CONCLUSION}

Most people live in a family community, either with a partner, children or parents. It is from this point of view that we are responsible not only to ourselves but also to others. It is important to take care of our social security in the event of unforeseen events such as unexpected death, loss of ability to work as a result of disability, serious illness, accident and more. It is best that none of this happens to us, but if it does, the money we get at that moment makes the situation at least a little easier, especially for those who are not in the best financial position.

Insurance is also extremely important for individuals who live alone, because if something happens to them, they depend on themselves. Given the pace of life that young people live, it is firstly and foremost important to arrange good accident insurance in the event of disability, as it is disability that can drastically change our lives. Given the long period of study, and consequently later employment, young people have little working life.

Young people in the age group up to the age of 35 are aware that life insurance is necessary for basic survival and that they will have to take care of it themselves, but very little is already being saved for this purpose. It is also important for them to have arranged insurance and social security for unforeseen situations in life such as accidents and serious illnesses, but many of them have not yet taken care of this. The main reason is that most young people have too low incomes.

Before buying insurance, it is important that the individual knows why he wants to buy insurance, that he knows what his appropriate sum insured is, and that he decides for how long he will buy insurance, whether it will be long-term or shortterm insurance.

In case of saving, he must decide what risk he will take. It is important to choose an offer that meets his needs and to look not only at the price of insurance, but above all at what he gains from it. The client must know the obligations and rights that he gets in the case of buying insurance.

\section{REFERENCES}

Bieber, C. (2019). What Types of Insurance Do You Need? https://www.fool.com/investing/what-typesof-insurance-do-you-need.aspx

Calsyn, M., \& Rosenthal, L., (2013). How the Affordable Care Act Helps Young Adults. https://www.americanprogress.org/issues/healthcare/ reports/2013/05/20/63792/how-the-affordable-careact-helps-young-adults/.

Cantiello, J., Fottler, M. D., Oetjen, D., \& Zhang, N. J. (2015). The impact of demographic and perceptual variables on a young adult's decision to be covered by private health insurance. BMC Health Services Research, 15, 195. https://doi.org/10.1186/s12913015-0848-6

Ćurak, M., Džaja, I., \& Pepur, S. (2013). The Effect of Social and Demographic Factors on Life Insurance Demand in Croatia. International Journal of Business and Social Science, 4(9), 65-72.

Deloitte Center for Health Solutions, (2015). Young adults and health insurance: not invincible - but perhaps convincible. Washington, DC: Deloitte Center for Health Solutions.

Dorsey, J. (2018). (Best) Health Insurance for Young Adults.

https://www.healthedeals.com/blog/save/youngadult-health-insurance/.

Gillespie, L. (2015). Five Things Young Adults Should Know About Buying Health Insurance. https://khn.org/news/five-things-young-adultsshould-know-about-buying-health-insurance/.

Kjosevski, J. (2012). The Determinants of Life Insurance Demand In Central and South-Eeastern Europe. International Journal of Economics and Finance, 4(3), 237-247. https://doi.org/10.5539/ijef.v4n3p237

Leong M. (2013). Why young adults need (or don't need) insurance. Financial post.

https://financialpost.com/personal-finance/youngmoney/why-young-adults-need-or-dont-needinsurance.

Levitt, L. (2015). Why health insurance literacy matters. JAMA, 313(6), 555-556. https://doi.org/10.1001/jama.2014.17419

Mercadante, K. (2021). Reality Check: Buying Life Insurance Young Saves Money. https://www.moneyunder30.com/buying-lifeinsurance-young-saves-money.

Morrow, S. (2021). Are young people still going without life insurance? L\&E. http://lewisellis.com/industryinsights/article/40134937-are-young-people-stillgoing-without-life-insurance

Peerson, A., \& Saunders, M. (2009). Health literacy revisited: what do we mean and why does it matter? Health Promotion International, 24(3), 285-296. https://doi.org/10.1093/heapro/dap014 
Price, J. H., Khubchandani, J., Dake, J. A., Thompson, A., Schmalzried, H., Adeyanju, M., \& Esprit, L. G. (2010). College students' perceptions and experiences with health insurance. Journal of the National Medical Association, 102(12), 1222. https://doi.org/10.1016/S0027-9684(15)30777-X

Staley, M. J., \& Carson, J. A. (2014). Health Insurance Among Young Adults Rebounds Post Recession. Carsey research. https://scholars.unh.edu/cgi/viewcontent.cgi?article= $1222 \&$ context $=$ carsey.

Sumit A. (2017). What Types of Insurance Policies Young People Must Have?

https://www.coverfox.com/generalinsurance/articles/types-of-insurance-policiesyoung-people-must-buy/.

Tacadena G. (2019). What's the key to attracting more young people to insurance? https://www.insurancebusinessmag.com/us/news/bre aking-news/whats-the-key-to-attracting-moreyoung-people-to-insurance-170716.aspx.

Tilley, L., Yarger, Y., \& Brindis, C. D. (2018). Young Adults Changing Insurance Status: Gaps in Health Insurance Literacy. Journal of Community Health. 43, 680-687. https://doi.org/10.1007/s10900-0180469-1

Wong, C. A., Asch, D. A., Vinoya, C. M., Ford, C. A., Baker, T., Town, R., \& Merchant, R. M. (2015). Seeing health insurance and HealthCare. gov through the eyes of young adults. Journal of Adolescent Health, 57(2), 137-143. https://doi.org/10.1016/j.jadohealth.2015.04.017

Yang L. (2016). Young Adults' Attitudes and Perceptions on Health Insurance and their Health Insurance Literacy Levels. All Theses, Dissertations, and Other Capstone Projects. Paper 617.

\section{FAKTORI KOJI UTIČU NA OSIGURANJE ZA MLADE}

Današnja vremena se brzo menjaju, ljudi postaju sve aktivniji, pa se često nalazimo u situaciji nad kojom nemamo kontrolu. $U$ današnje vreme znamo mnoge vrste osiguranja pomoću kojih možemo da se pobrinemo za svoju finansijsku sigurnost. Važno je da pojedinci odaberu najprikladniju vrstu osiguranja u skladu sa svojim potrebama i životnim vekom. Izuzetno je važno da mladi što pre počnu da štede za svoju budućnost u vidu životnog osiguranja. Glavni cilj ovog rada je utvrđivanje koliki je udeo mladih koji već imaju osiguranje ili već razmišljaju o njemu, a zašto ne. Zanimalo nas je i šta su presudni faktori zbog kojih se mladi odlučuju za kupovinu osiguranja, a zašto ne. Istraživanja su pokazala da su mladi svesni značaja osiguranja, ali većina njih nema odgovarajuća finansijska sredstva i nedovoljno je informisana o vrstama osiguranja.

Ključne reči: Osiguranje; Životno osiguranje; Uticajni faktori; Mladi. 